\title{
Trail races in protected mountain areas and their effects on sustainable development
}

\author{
Joan Babí, Eduard Inglés \& Susanna Soler \\ Keywords: trail running, sustainability, impact, event management, sport
}

\section{Abstract}

This article addresses the degree of sustainability generated by trail races in the development of the territory in protected mountain areas, focusing on the extent of the protection of natural areas and on the kinds of entities that organize these events. It is based on the feedback from 95 questionnaires completed by a sample of organizers of trail-race events held within 26 protected mountain areas in Catalonia in 2015. Analysis allowed us to identify those trail races with the most exemplary practices. No differences in the degree of sustainable development were found with regard to the degree of protection of natural areas. Profit-making organizations generate a greater degree of sustainability where development of the territory is concerned than do non-profit entities. The study provides protected mountain area managers and trail-race managers with an instrument with which to diagnose the impact that such races have on the land.

\section{Introduction}

Although trail races have recently acquired great importance in our society (Federación Española de Deportes de Montaña y Escalada 2011; The Outdoor Foundation 2010), as a category they have been the object of only a few studies (Getz \& McConnell 2014); as yet we have little knowledge of the effects these events have on the environment, and even less of how protected natural area managers and trail-race organizing entities act when it comes to fostering sustainable development of the land ( $\mathrm{Ng}$ et al. 2018). Additionally, we note the need for specific regulation of sports activities in natural areas in order to promote their sustainability (Havlick et al. 2016).

In recent years, there has been an exponential increase in the number of trail races. This growth has been seen in various parts of the world, especially in North America (Hoffman et al. 2010; The Outdoor Foundation 2010). Over the last 5 years, trail races have tripled across Catalonia, reaching a total of 447 in 2015 (Ropits Social Running 2016); moreover, increases in the number of trail races have also been seen in Catalonia's natural protected areas. Trail races affect the environment, as Inglés et al. (2016) reveal in the case of the Matagalls-Montserrat Trail Race, which generated severe soil erosion at the top of Matagalls mountain and created serious congestion in local villages, thereby hindering local communications and traffic. Thus, the increase in trail races may have major effects on the environment.

Concern with preserving the natural environment has led the Federación Española de Deportes de Montaña y Escalada (Spanish Federation of Mountain and Mountaineering Sports) (2011) to set initiatives in motion within protected natural areas with the aim of finding a balance between conservation and the practice of nature sports like mountain races.
The kind of organization entrusted with the management of mountain races is pivotal when it comes to assessing the effects these events have on the environment. Andersson \& Getz (2009) differentiate between the implications of the various kinds of organization: the main objective of private entities is economic profit, as their survival depends on this; public entities focus on social benefit, independently of financial outlay; non-profit organizations give priority to the interests shared by their members, thereby making it possible to realize a dream and / or create jobs. In addition, some studies (Garrod \& Fyall 2000; Inglés et al. 2016; Inglés \& Puig 2015) refer to the differences in the perception and management of sustainability issues depending on the type of organization. Garrod \& Fyall (2000, p. 690) state that "there is nevertheless a substantial affinity between managers' perceptions of the fundamental mission of heritage attractions and the principles of sustainable development," meaning that sustainability will be influenced not only by the kind of organization but also by the particular visions of the organization's managers.

This study sets out to define the effect of trail races on the sustainable development of the territories in which they take place. It consists of an analysis of the races' effects on the ecological, social, economic and institutional dimensions of sustainable practice in relation to the degree of protection of the natural area and the type of organization managing the event. The assessment is based on the views of the events' managers. Thus, this paper offers a theoretical and methodological approach to this almost unexplored field by showing a concrete case of conflict in Catalonia and using the increase of trail races as a small step towards promoting the sustainability of sports practice in natural areas. 


\section{Theoretical framework}

The focus of the study is the trail race, defined as a pedestrian race open to all, in a natural environment (mountain, desert, forest, plain ...) with minimal possible paved or asphalt road (which should not exceed 20\% of the total course) (International Trail Running Association 2013). In this section, we define the theoretical concepts on which the present study is founded: sustainable development and each of its dimensions.

\section{Sustainable development}

In this study, sustainable development is conceived as a system that comprises four dimensions (social, economic, ecological and political-institutional), of the interactions of the indicators within each of the dimensions, and of the interactions between the dimensions themselves (Cottrell et al. 2007; Inglés 2013; Inglés \& Puig 2015; Inglés et al. 2016). Several studies reveal the complexities involved when it comes to analysing the effects of these dimensions on sustainable development (Barajas et al. 2012; Liu 2003); nonetheless, all the studies assert that sustainable development takes place when a positive effect is observed within all four dimensions.

The ecological dimension is affected by the material, energy and spatial requirements that must be met if an event is to take place (Spangenberg 2002a). Liu (2003) refers to the impact of the event on the environment and the long-term sustainability of natural resources as the ecological carrying capacity of the event under scrutiny. In keeping with previous studies (Federación Española de Deportes de Montaña y Escalada 2011; Gibson et al.
2012; Liu 2003; Luque Valle et al. 2011; Spangenberg 2002a), ecological impact is measured by the indicators shown in Table 1.

The social dimension is related to the repercussions of events at inter-relational levels (Richards et al. 2013), i.e. between the stakeholders involved in the decisionmaking processes. Taks (2013) highlights the socializing effect of small-scale events, positive aspects of which are increased opportunities to obtain new experiences and meet people. Djaballah et al. (2015) put forward an extended definition of social impact, which encompasses recognized social capital, well-being, the consolidation of collective identities, participation in sport, urban regeneration and human capital. Kerwin et al. (2015) underline that volunteering is a collective experience and a direct outcome of social capital. For their part, Gibson et al. (2012) analysed the social impact of six small-scale sporting events.

The economic dimension refers to the impact on the local community's financial well-being, often indicated by job creation and injections of money from outside (Henderson 2007). Agha \& Taks (2015) identified the importance to the territory of investment on the part of organizing entities, of the number of jobs created, and of the total amount invested in the area (by buying products, renting facilities ...). Veltri et al. (2009) studied the effect of spectators on the economic dimension in terms of existing accommodation and catering facilities.

The institutional dimension refers to the effects of interpersonal processes, such as communication and cooperation, which result in the exchange of information and systems of rules governing the interaction of

Table 1 - Indicators for measuring the sustainable development of trail races.

\begin{tabular}{|c|c|c|}
\hline \multirow{2}{*}{$\begin{array}{l}\text { Dimensions of } \\
\text { analysis } \\
\text { Ecological effect }\end{array}$} & \multicolumn{2}{|c|}{ Indicators of sustainable development level of trail races } \\
\hline & Number of participants & Total number of trail runners \\
\hline & Total distance & Total number of linear kilometres covered \\
\hline & Environmental protocol & Existence (or not) of environmental protocol \\
\hline & Type of terrain & Percentage of terrain: no path, narrow path, wide path, asphalt \\
\hline & Circulation plan & Existence (or not) of circulation plan \\
\hline \multirow[t]{5}{*}{ Social effect } & Number of other sports offers & Total number of sports activities parallel to the trail race \\
\hline & Number of services offered & Total number of services offered during the trail race \\
\hline & Assessment of participants' satisfaction & Numerical value for the trail runners' degree of satisfaction \\
\hline & Number of volunteers & Total number of volunteers involved in implementing the trail race \\
\hline & Investment in social events & Total amount of money allocated for social events \\
\hline Economic effect & $\begin{array}{l}\text { Accommodation, catering, transport and medi- } \\
\text { cal assistance }\end{array}$ & $\begin{array}{l}\text { Existence (or not) of services: accommodation, catering, transport, } \\
\text { medical assistance }\end{array}$ \\
\hline \multirow{5}{*}{$\begin{array}{l}\text { Institutional } \\
\text { effect }\end{array}$} & Number of public entities & Total number of public entities involved in the event \\
\hline & Assessment of relationship with public entities & $\begin{array}{l}\text { Numerical value for the degree of satisfaction regarding the relation- } \\
\text { ship with public entities }\end{array}$ \\
\hline & Number of private entities & Total number of private entities involved in the event \\
\hline & Assessment of relationship with private entities & $\begin{array}{l}\text { Numerical value for the degree of satisfaction regarding the relation- } \\
\text { ship with private entities }\end{array}$ \\
\hline & Total amount of subsidies or sponsorship money & Total amount of money for trail race subsidies or sponsorship \\
\hline
\end{tabular}




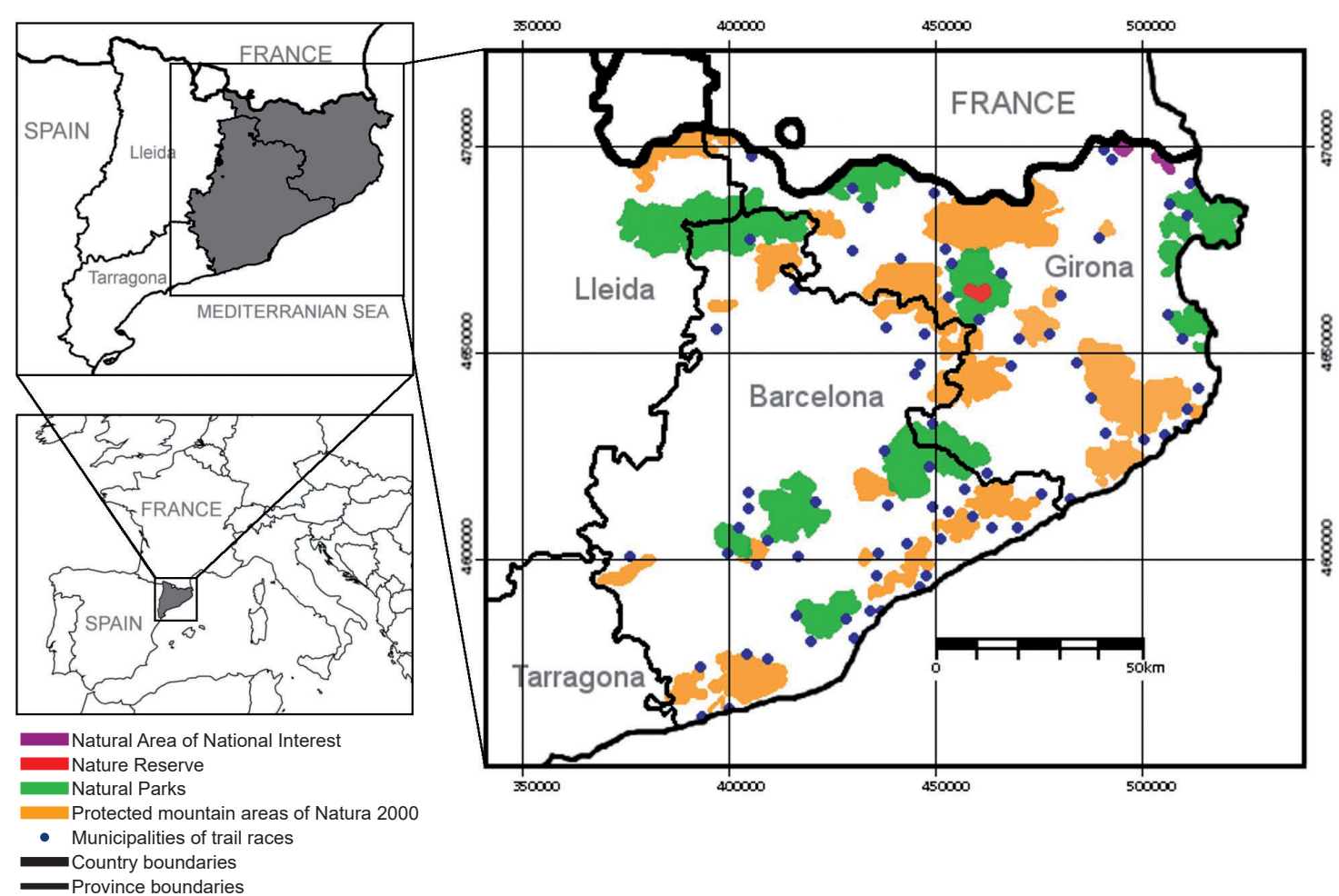

Figure 1 - Geographical distribution of trail races in protected natural areas in Barcelona and Girona provinces in 2015. Runedia Database. Map: J. Babí.

members of a society (Spangenberg 2002b). In their analysis of the institutional dimension, Cottrell et al. (2007) highlighted the importance of establishing good relations with stakeholders. Dredge \& Whitford (2010) contended that having a broad range of stakeholders generates a positive effect on the institutional dimension. In this same context, Inglés et al. (2016) and Luque Valle et al. (2011) concluded that an increased number of network relationships and the application of collaboration processes between stakeholders engender greater sustainability in territorial development.

\section{Method}

This study adopts a descriptive approach to present trail races held on protected natural land in Barcelona and Girona provinces (Catalonia, Spain). During faceto-face meetings, one questionnaire each was handed to the people responsible for organizing a trail race. The administration of the questionnaire was supported by seven people (main researcher or trained collaborators). Data collection took place between May and November 2016. During the interviews, which took an average of forty-eight minutes, interviewees were asked to supply the indicators for each of the four abovementioned dimensions (Table 1) that conceptualize the degree of sustainable development of trail races.

\section{Population of trail races}

While it is easy to identify the growth and expansion of the actual events, the majority of countries are una- ware of the increases in their event populations (Getz \& Page 2016), where population refers to the number of similar events which are competing for finite resources in a particular region (Getz \& Andersson 2016). This applies also to the trail-race population in Catalonia, where the absence of any need for an official licence to run an event makes it difficult to ascertain the exact number of trail races and, consequently, the exact number of trail runners.

Our analysis of the situation in Catalonia where trail races are concerned was made as accurate as possible through the use of a variety of sources (web pages and Federation of Hiking Entities of Catalonia databases), and by analysing 206 trail races that took place in 2015 in the protected mountain areas of Barcelona and Girona provinces.

\section{Sample}

We conducted random sampling of 206 trail races in Barcelona and Girona provinces. In order to ensure the representativity and validity of the results obtained, we aimed to identify 134 trail races that represented a margin of error of $5 \%$ and a level of confidence of $95 \%$. Unfortunately, for access reasons, our final sample comprised 95 trail races $(46.1 \%$ of the population), with a margin of error of $7.4 \%$ and a level of confidence of $95 \%$. For the 95 races, a total of 88 managers were involved, 4 of them having organized more than one race.

The managers were aged between 25 and 73 years old (42.94 \pm 11.92$) ; 83$ were men $(94.32 \%)$ and 5 were 
Table 2 - Sample characteristics.

\begin{tabular}{|r|r|r|r|r|r|r|}
\hline Percentiles & $\begin{array}{l}\text { Number of } \\
\text { participants }\end{array}$ & $\begin{array}{l}\text { Race's longest } \\
\text { distance }(\mathbf{k m})\end{array}$ & $\begin{array}{l}\text { Positive } \\
\text { slope }(\mathbf{m})\end{array}$ & $\begin{array}{l}\text { Accumulated } \\
\text { slope }(\mathbf{m})\end{array}$ & $\begin{array}{l}\text { Highest } \\
\text { altitude (m) }\end{array}$ & $\begin{array}{l}\text { Lowest } \\
\text { altitude (m) }\end{array}$ \\
\hline 10 & 77 & 10.5 & 295.2 & 475.6 & 310.8 & 0 \\
\hline 20 & 151 & 15.0 & 559.0 & 952.0 & 400.0 & 41.0 \\
\hline 30 & 191 & 20.0 & 749.0 & 1354.4 & 461.6 & 101.6 \\
\hline 40 & 241 & 21.0 & 949.4 & 1702.4 & 557.6 & 157.0 \\
\hline 50 & 290 & 22.1 & 1100.0 & 2000.0 & 663.0 & 200.0 \\
\hline 60 & 389 & 27.0 & 1264.0 & 2230.0 & 877.2 & 289.0 \\
\hline 70 & 500 & 32.0 & 1600.0 & 3020.0 & 1236.6 & 400.0 \\
\hline 80 & 700 & 42.0 & 2198.0 & 4024.0 & 1513.6 & 584.4 \\
\hline 90 & 831 & 55.0 & 4020.0 & 6080.0 & 2071.2 & 802.0 \\
\hline
\end{tabular}

women (5.68\%). Their educational levels were as follows: university studies $(42.05 \%)$, professional training $(32.95 \%)$, secondary studies $(12.50 \%)$, elementary studies $(4.55 \%)$, PhD studies (4.55\%), other postgraduate studies $(4.55 \%)$. The managers organized their first trail race in 2011 ( \pm 6$)$, since when 52 of them $(51.14 \%)$ have organized other trail races. The types of organization to which the managers belonged were sports associations or clubs (48.86\%), non-sporting associations $(12.5 \%)$, events companies $(7.95 \%)$, other private associations $(20.46 \%)$, and public entities $(10.23 \%)$.

The 95 trail races on which this paper focuses took place in 84 municipalities in 20 Catalan comarques (small territorial divisions). Routes passed through different protected mountain areas: 1 Natural Area of National Interest $(\mathrm{n}=3), 1$ Nature Reserve $(\mathrm{n}=1), 11$ Natural Parks $(\mathrm{n}=37)$, and 26 protected mountain areas belonging to the Natura 2000 network $(\mathrm{n}=54)$.

In accordance with Natural Areas Law 12/1985 and Decree 328/1992, by which the Catalan Plan for Areas of Natural Interest was enacted, the following designations of protected areas are identified in descending order of degree of protection: Natural Areas of National Interest. medium sized, with the aim of protecting unique scientific, landscape or educational characteristics; $\mathrm{Na}$ ture Reserves: small sized, created to preserve the existing natural ecosystems entirely; Natural Parks: created in order to bring into line with each other the protection of the natural conditions, the use of their resources, and the activities of their inhabitants; Protected Mountain Areas included in the Natura 2000 network, which aims to protect natural habitats and species and to make the areas compatible with the development of human activity.

Figure 1 illustrates the location in Catalonia of the sample of trail races and the protected natural areas in which they took place.

Table 2 provides the basic characteristics of the sample ( $n=95$ ), giving the percentile values for: total number of participants, length of the longest trailrace circuit, positive and accumulated slopes, and highest and lowest altitudes.

\section{Questionnaire}

A questionnaire was designed to elicit perceptions of the indicators for each of the four dimensions (ecological, social, economic and institutional; see Table 1) that conceptualize the degree of sustainable development of trail races. The questionnaire comprised 57 questions, combining different types of question: text fields (13); multiple-choice questions (2 questions requiring a single response; 1 question allowing multiple possible answers); scales (15); mixed (26).

\section{Data collection}

In order to cover as many trail races as possible and to ensure proper compliance, and due to the considerable amount of time needed to complete the questionnaire, it was distributed in standardized face-toface interviews; the questions were formulated one by one, following the exact order of the survey. The main researcher or trained collaborators contacted each of the trail race managers and agreed a date to meet at his / her place of work. As already mentioned, interviews lasted an average of 48 minutes.

\section{Indices of indicators}

Due to the complexity of the operationalization (Table 1) and based on the research of Inglés et al. (2016) and Inglés \& Puig (2015), an index was defined with which to group together the corresponding concept indicators. Its definition and the calculation process are explained as follows:

Sustainability index. This assigns a quantitative value to the effects of the different trail races on the degree of sustainability of the development of the area. This value is established as the mean of the four Dimension indices.

Index for each dimension. A quantitative value was assigned for the effect of each of the four dimensions on the sustainability of development in the area. This value was the mean of the set of values for the corresponding indicators.

Indicator values. A set of numerical values (from 0 to 10), corresponding to the multiple indicators of a dimension, was established for each of the indicators. The value depended on whether the indicator was close to (10) or far from (0) a theoretical ideal achievement for sustainable development. This ideal achievement is an unrealistic construct, based on previous studies (Inglés 2013; Inglés et al. 2016), that perfectly accomplishes the principles of sustainability. For ex- 
Table 3 - Dimensions indices (Ecological, Social, Economic and Institutional) and Sustainability indices, by trail race.

\begin{tabular}{|c|c|c|c|c|c|c|c|c|c|c|c|c|c|c|c|c|c|c|c|c|c|c|c|c|c|c|c|c|c|c|c|c|}
\hline uster & $A$ & A & A & $\mathrm{A}$ & $\mathrm{A}$ & A & A & A & $\mathrm{A}$ & $\mathrm{A}$ & $A$ & A & A & $\mathrm{A}$ & $\mathrm{A}$ & A & A & A & A & $\mathrm{A}$ & $\mathrm{A}$ & . & A & A & 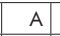 & A & A & A & & & 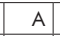 & A \\
\hline ail race ID & 1 & 2 & 3 & 4 & 5 & 6 & 7 & 8 & 9 & 10 & 11 & 12 & 13 & 14 & 15 & 16 & 17 & 18 & 19 & 20 & 21 & 22 & 23 & 24 & 25 & 26 & 27 & 28 & 29 & 30 & 31 & 32 \\
\hline & 3.2 & .5 & 3.7 & .8 & 4.0 & 4.2 & \begin{tabular}{|l|}
4.0 \\
\end{tabular} & 2.5 & 4.0 & 3.0 & 3.0 & 4.5 & 2.3 & 5.8 & 4.5 & 5.7 & 4.5 & \begin{tabular}{|l|}
5.7 \\
\end{tabular} & \begin{tabular}{|l|}
5.3 \\
\end{tabular} & \begin{tabular}{|l|}
5.3 \\
\end{tabular} & \begin{tabular}{|l|}
5.0 \\
\end{tabular} & 5.8 & 4.0 & 5.8 & 5.7 & 1.3 & 5.5 & 5.5 & \begin{tabular}{|l|l|}
4.7 \\
\end{tabular} & 4.5 & 4.7 & 4.8 \\
\hline C.inder & 4.5 & 3 & + & 5.0 & \begin{tabular}{|l|l|}
4.8 \\
\end{tabular} & \begin{tabular}{|l|}
3.7 \\
\end{tabular} & \begin{tabular}{|l|}
3.3 \\
\end{tabular} & 4.5 & 2.7 & 6.0 & 6.2 & \begin{tabular}{|l|}
5.7 \\
\end{tabular} & 5.5 & .0 & 3.7 & .0 & 5.5 & \begin{tabular}{|l|}
4.0 \\
\end{tabular} & 5.2 & \begin{tabular}{|l|}
3.8 \\
\end{tabular} & \begin{tabular}{|l|}
7.3 \\
\end{tabular} & 4.8 & 5.7 & \begin{tabular}{|l|}
4.2 \\
\end{tabular} & \begin{tabular}{|l|} 
\\
\end{tabular} & \begin{tabular}{|l|}
5.7 \\
\end{tabular} & \begin{tabular}{|l|}
3.7 \\
\end{tabular} & \begin{tabular}{|l|}
4.2 \\
\end{tabular} & 7.2 & 5.8 & 5.0 & $\begin{array}{l}3.7 \\
\end{array}$ \\
\hline ECON & 3 & & & 5.7 & 0 & 5.0 & \begin{tabular}{|l|} 
\\
\end{tabular} & & & 3 & 6.7 & 3.3 & \begin{tabular}{|l|} 
\\
\end{tabular} & 7 & .7 & 3 & 5.7 & 5.0 & 6.3 & 6.0 & 2.7 & \begin{tabular}{|l|}
5.7 \\
\end{tabular} & 6.3 & \begin{tabular}{|l|}
9.0 \\
\end{tabular} & \begin{tabular}{|l|}
5.7 \\
\end{tabular} & \begin{tabular}{|l|}
9.7 \\
\end{tabular} & \begin{tabular}{|l|}
8.0 \\
\end{tabular} & \begin{tabular}{|l|}
5.7 \\
\end{tabular} & 6.0 & 6.0 & 8.7 & 3.7 \\
\hline & & & & & & 4 & 6 & & & & 7 & \begin{tabular}{|l|l|} 
& \\
\end{tabular} & 8.3 & 3 & 4 & 8.0 & 6.7 & \begin{tabular}{|l|}
7.8 \\
\end{tabular} & 5.8 & 7.6 & 8 & 6.7 & 7.0 & \begin{tabular}{|l|}
4.5 \\
\end{tabular} & 8.2 & 7.5 & \begin{tabular}{|l|}
7.0 \\
\end{tabular} & \begin{tabular}{|l|}
9.2 \\
\end{tabular} & 6.9 & 6 & 7.4 & 8.6 \\
\hline JSin & 4.3 & & & 4.8 & 4.8 & \begin{tabular}{|l|}
4.8 \\
\end{tabular} & \begin{tabular}{|l|l|}
4.8 \\
\end{tabular} & 5.0 & 5.0 & 5 & 5.4 & 5.4 & \begin{tabular}{|l|}
5.5 \\
\end{tabular} & 5.5 & 5.6 & 5.6 & 5.6 & \begin{tabular}{|l|}
5.6 \\
\end{tabular} & \begin{tabular}{|l|}
5.7 \\
\end{tabular} & 5.7 & 5.7 & 5.8 & \begin{tabular}{|l|l|}
5.8 \\
\end{tabular} & 5.9 & 5.9 & 6.0 & 6.0 & 6.1 & 6.2 & 6.2 & 6.4 & 6.4 \\
\hline luster & B & B & B & B & B & B & B & B & B & & B & B & B & B & B & & B & B & B & & & & & & & & & & & & & \\
\hline Trail & 34 & 35 & 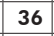 & 37 & 38 & 39 & 40 & 41 & 42 & 43 & 44 & 45 & 46 & 47 & 8 & 49 & 50 & 51 & 52 & 53 & 54 & 55 & 56 & 57 & 58 & 59 & 60 & 61 & 62 & 63 & 64 & \\
\hline $\mathrm{ECOL}$ & 2.3 & 1 & 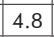 & 2.8 & 2.5 & \begin{tabular}{|l|}
5.5 \\
\end{tabular} & \begin{tabular}{|l|}
6.2 \\
\end{tabular} & D. & 6.7 & 5.2 & 5.3 & \begin{tabular}{|l|}
3.7 \\
\end{tabular} & \begin{tabular}{|l|}
7.0 \\
\end{tabular} & 4.2 & \begin{tabular}{|l|}
4.8 \\
\end{tabular} & 4.8 & 5.8 & \begin{tabular}{|l|}
6.3 \\
\end{tabular} & 5.8 & 3.2 & \begin{tabular}{|l|}
4.8 \\
\end{tabular} & 5.7 & 6.3 & \begin{tabular}{|l|}
5.3 \\
\end{tabular} & 6.7 & \begin{tabular}{|l|}
4.5 \\
\end{tabular} & 3.5 & \begin{tabular}{|l|}
4.5 \\
\end{tabular} & 6.3 & 5.3 & 5.8 & \\
\hline SOCindex & 2.0 & 2.0 & 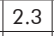 & 3.0 & 3.7 & 2.7 & \begin{tabular}{|l|}
3.7 \\
\end{tabular} & 1.8 & 5 & 2 & 2.3 & 2.8 & 2.3 & 2.5 & 3.0 & 3 & 7 & 2.5 & \begin{tabular}{|l|}
2.7 \\
\end{tabular} & 0 & 3.3 & 3.2 & 3.5 & 3.3 & 3.2 & 5 & 3 & 4.5 & 2.8 & 2.8 & .0 & \\
\hline $\mathrm{ECOI}$ & 0 & 0 & & .7 & 3.3 & 0 & 0 & & 1.7 & 0 & 0.3 & \begin{tabular}{|l|}
1.0 \\
\end{tabular} & 2. & 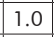 & 1.0 & 0.3 & 0.7 & \begin{tabular}{|l|}
1.7 \\
\end{tabular} & 2.0 & \begin{tabular}{|l|}
1.7 \\
\end{tabular} & \begin{tabular}{|l|}
2.0 \\
\end{tabular} & 0.3 & $\begin{array}{l}1.0 \\
\end{array}$ & 0.7 & .7 & .7 & 2 & 1.3 & 3 & 3 & 4.0 & \\
\hline & 5 & 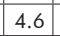 & & & 6 & 4.1 & 2.6 & & 2.2 & 5.0 & 5.9 & 6.7 & 2.2 & 8 & 5.7 & 6.6 & 6.1 & \begin{tabular}{|l|}
4.8 \\
\end{tabular} & 4.8 & 6.5 & 5.3 & 6.4 & \begin{tabular}{|l|} 
\\
\end{tabular} & 6.3 & \begin{tabular}{|l|l|}
4.1 \\
\end{tabular} & 6.3 & 5.4 & 5.9 & 6.8 & 8.8 & 8.4 & \\
\hline SUSin & 2. & \begin{tabular}{|l|}
2.7 \\
\end{tabular} & 2.9 & 3.0 & 3.0 & 3.1 & 3.1 & 3. & 3.3 & 3.3 & 3.5 & 3.6 & 3.6 & 3.6 & 3.6 & 3.7 & 3.8 & 3.8 & \begin{tabular}{|l|}
3.8 \\
\end{tabular} & 3.8 & 3.9 & 3.9 & 3.9 & 3.9 & 3.9 & 4.0 & 4.0 & 4.1 & 4.1 & 4.1 & 4.6 & \\
\hline & $c_{2}$ & C & C & C & C & c & C & c & $c$ & C & & ( & C & C & & & 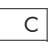 & & C & C & & & & & C & C & & & T) & & $\mathrm{N}$ & N \\
\hline Trail & 65 & 66 & 67 & 68 & 69 & 70 & 71 & 72 & 73 & 74 & 75 & 76 & 77 & 78 & 79 & 80 & 81 & 82 & 83 & \begin{tabular}{|l|}
84 \\
\end{tabular} & 85 & 86 & \begin{tabular}{|l|}
87 \\
\end{tabular} & 88 & 89 & 90 & 91 & & 92 & 93 & 94 & 95 \\
\hline $\mathrm{ECOL}$ & 8.0 & 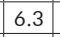 & \begin{tabular}{|l|}
8.3 \\
\end{tabular} & 6.5 & 5.5 & 5.0 & \begin{tabular}{|l|}
8.3 \\
\end{tabular} & \begin{tabular}{|l|l} 
\\
\end{tabular} & 8.5 & \begin{tabular}{ll|}
7.2 \\
\end{tabular} & 6.5 & \begin{tabular}{|l|}
7.2 \\
\end{tabular} & \begin{tabular}{|l|l|}
9.7 \\
\end{tabular} & 6.0 & 6.2 & 6.5 & 8 & \begin{tabular}{|l|}
6.0 \\
\end{tabular} & 6.5 & \begin{tabular}{|l|l|}
7.7 \\
\end{tabular} & 6.2 & 7.7 & \begin{tabular}{|l|}
6.7 \\
\end{tabular} & \begin{tabular}{|l|}
7.8 \\
\end{tabular} & \begin{tabular}{|l|}
7.5 \\
\end{tabular} & \begin{tabular}{|l|l|}
7.0 \\
\end{tabular} & 7.0 & & 4.3 & 4.5 & 5. & 4.0 \\
\hline & 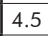 & & 3.8 & & 4. & + & $t$ & 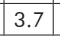 & 3.8 & \begin{tabular}{ll|}
4.5 \\
\end{tabular} & 3.7 & \begin{tabular}{|l|}
5.3 \\
\end{tabular} & \begin{tabular}{|l|}
1.8 \\
\end{tabular} & (2) & 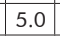 & 4.0 & 2 & \begin{tabular}{|l|} 
\\
\end{tabular} & 5.0 & \begin{tabular}{|l|}
3.8 \\
\end{tabular} & \begin{tabular}{|l|}
4.8 \\
\end{tabular} & \begin{tabular}{|l|}
4.3 \\
\end{tabular} & 4.8 & 4.3 & \begin{tabular}{|l|}
5.8 \\
\end{tabular} & \begin{tabular}{|l|}
4.8 \\
\end{tabular} & \begin{tabular}{|l|}
5.7 \\
\end{tabular} & & 3 & 4.2 & 3.2 & 4.3 \\
\hline & 0 & & 0 & & & 3 & & & 1.3 & & 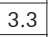 & 1.3 & 4. & 0 & & t & 3 & \begin{tabular}{|l|}
3.3 \\
\end{tabular} & \begin{tabular}{|l|l|}
4.7 \\
\end{tabular} & 0 & \begin{tabular}{|l|}
4.3 \\
\end{tabular} & 3.0 & 5.0 & \begin{tabular}{|l|}
3.0 \\
\end{tabular} & 3.0 & 7 & 7 & & $1 / a$ & & & \\
\hline INSind & 3. & \begin{tabular}{ll|}
6.6 \\
\end{tabular} & $D_{-1}$ & 6.5 & 7.1 & 6.7 & \begin{tabular}{|l|l}
4.9 \\
\end{tabular} & 6.3 & 5.9 & 3 & 0 & 6. & 4.3 & 6.4 & 8.8 & 6.3 & 6.5 & 6.6 & 5.2 & 6.5 & \begin{tabular}{|l|l|}
7.1 \\
\end{tabular} & 7.5 & 2 & 6 & 7.6 & 7.7 & \begin{tabular}{|l|}
7.0 \\
\end{tabular} & & \begin{tabular}{|l|}
8.9 \\
\end{tabular} & 8 & 6.0 & 5.5 \\
\hline USindex & \begin{tabular}{|l|l} 
\\
\end{tabular} & \begin{tabular}{|l|}
4.4 \\
\end{tabular} & 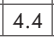 & \begin{tabular}{|l|}
4.7 \\
\end{tabular} & 4.7 & \begin{tabular}{|l|l}
4.7 \\
\end{tabular} & \begin{tabular}{|l|l|}
4.8 \\
\end{tabular} & \begin{tabular}{|l|l}
4.9 \\
\end{tabular} & \begin{tabular}{|l|l|}
4.9 \\
\end{tabular} & 4.9 & 5.0 & \begin{tabular}{|l|l|}
5.1 \\
\end{tabular} & \begin{tabular}{|l|l|}
5.1 \\
\end{tabular} & 5.2 & 5.2 & \begin{tabular}{ll|} 
\\
\end{tabular} & 5.2 & \begin{tabular}{|l|l|}
5.3 \\
\end{tabular} & \begin{tabular}{|l|}
5.3 \\
\end{tabular} & 5.5 & \begin{tabular}{|l|}
5.6 \\
\end{tabular} & 5.6 & \begin{tabular}{|l|}
5.7 \\
\end{tabular} & 5.7 & 6.0 & \begin{tabular}{|l|l|}
6.1 \\
\end{tabular} & \begin{tabular}{|l|l|}
6.1 \\
\end{tabular} & & $\mathrm{n} / \mathrm{a}$ & $n / a$ & $n / a$ & i/a \\
\hline
\end{tabular}

$A, B$ and $C=$ Different clusters of trail races; $N=$ Uncategorised trail races; Bold trail race IDs = races with certain balance between different indices.

ample, in the case of the number of participants or the total effective distance, the ideal achievement of sustainability would be 0 trail runners and 0 kilometres - an unreal situation that allows us to establish a scale of values to classify the real trail races analysed. Where the number of participants was concerned, therefore, the highest value (10 points) was given to the race with the lowest number of participants, and the lowest value $(0$ points $)$ to the one with the greatest number. This process was repeated for all the indicators that form each dimension.

The trail races were then classified and given an overall score on the same 0-10 scale.

Equation 1 below summarizes the process of obtaining the sustainability index (SUSindex) through each dimension index $\left(\bar{X}_{\mathrm{j}}\right)$ : Ecological index (ECOLindex), Social index (SOCindex), Economic index (ECONindex), and Institutional index (INSindex). The score for each of the four dimensions is the mean of the relevant indicators $\left(x_{i}\right)$; the values obtained are compressed into a 0 to 10 scale. The average of these four values results in the sustainability index (maximum value 10 points).
Equation 1 - Calculation of Dimensions index and Sustainability index

$\bar{X}_{j}=\frac{\sum_{i=1}^{n} x_{i}}{n} ;$ SUSindex $=\frac{\sum_{i=1}^{4} \bar{X}_{i}}{4}$

After the indices have been calculated, various statistical analyses can be carried out. First, a k-means cluster analysis of the different indices allows us to categorize the trail races according to their dimensions index. Second, the clusters can be analysed by a Pearson's correlation of all indices. Finally, a Kruskal-Wallis Test (a non-parametric analysis), reveals $\mathrm{H}$ values and their significance; a Mann-Whitney test is then used to compare pairs of indices from previously identified clusters (from the k-analysis), type of natural area, and type of organization.

\section{Results}

Analysis of the results shows the different degrees of sustainability in the development of the areas where trail races are held. The correlation between

Table 4 - Categorization of trail races by dimensions index (Ecological, Social, Economic and Institutional) and Sustainability index, by trail race.

\begin{tabular}{|l|l|l|l|l|l|}
\cline { 2 - 5 } \multicolumn{1}{c|}{} & $\begin{array}{l}\text { Cluster A } \\
(\mathbf{n}=\mathbf{3 3})\end{array}$ & $\begin{array}{l}\text { Cluster B } \\
(\mathbf{n}=\mathbf{3 1})\end{array}$ & $\begin{array}{l}\text { Cluster C } \\
(\mathbf{n}=\mathbf{2 7})\end{array}$ & Kruskal-Wallis & $\begin{array}{l}\text { Comparisons by } \\
\text { Mann-Whitney }\end{array}$ \\
\cline { 2 - 5 } \multicolumn{1}{c|}{} & \multicolumn{4}{c|}{ Mean (SD) } \\
\hline ECOLindex & $4.32(1.38)$ & $4.98(1.26)$ & $6.94(1.07)$ & $\mathrm{H}(2)=43.863^{* * * *}$ & $\mathrm{C}^{* * * *}>\mathrm{A}, \mathrm{B}$. \\
\hline SOCindex & $4.80(1.08)$ & $2.96(0.72)$ & $4.36(0.84)$ & $\mathrm{H}(2)=42.390^{* * * *}$ & $\mathrm{~B}^{* * * *}<\mathrm{A}, \mathrm{C}$. \\
\hline ECONindex & $5.93(1.84)$ & $1.24(1.02)$ & $2.95(1.57)$ & $\mathrm{H}(2)=59.189^{* * * *}$ & $\mathrm{~B}^{* * * *}<\mathrm{A}, \mathrm{C} ; \mathrm{C}^{* * * *}<\mathrm{A}$. \\
\hline INSindex & $7.08(1.08)$ & $5.13(1.39)$ & $6.40(1.09)$ & $\mathrm{H}(2)=32.198^{* * * *}$ & $\mathrm{~B}^{* * * *}<\mathrm{A}, \mathrm{C} ; \mathrm{C}^{*}<\mathrm{A}$. \\
\hline SUSindex & $5.53(0.62)$ & $3.58(0.48)$ & $5.16(0.50)$ & $\mathrm{H}(2)=62.497^{* * * *}$ & $\mathrm{~B}^{* * * *}<\mathrm{A}, \mathrm{C} ; \mathrm{C}^{*}<\mathrm{A}$. \\
\hline
\end{tabular}


each index was analysed to ascertain the internal coherence between the SUSindex and its dimension indices. Subsequently, we conducted analysis of the relation between each dimension and (1) the degree of protection of the natural protected area; (2) the type of organization that manages the event.

\section{Index of sustainability}

In this section, we present the effects of each trail race analysed on each of the dimensions of sustainable development, with the aim of identifying the effects on the global degree of sustainability. The numerical data is presented in Table 3, where the value of each dimension index $\left(\bar{X}_{\mathrm{j}}\right)$ is given as a number from 1 to 10. Table 3 shows, in ascending order, which trail races have a more positive effect on the sustainable development of the territory. The three categories A, B and C emerged from a k-means cluster analysis of the different indices. Also included in Table 3 is the category for races with unknown data, because their managers preferred not to respond some financial questions. It can be seen that $70.5 \%$ of the races maintain a certain balance between the different indices (numbers of races in bold that have minimum $\bar{x}_{\mathrm{j}} 3.3$ and / or maximum $\left.\bar{x}_{j}>6.6\right)$. On the other hand, $29.5 \%$ present major variance between dimensions.

The main characteristics of three clusters are presented in Table 4. Cluster A presents middle-high values in all indices, but outstandingly high values in the ECONindex and INSindex, which means a good degree of sustainability, especially regarding institutional and economic effects. Cluster B has middle-low values in all indices but, most notably, low values for
Table 5 - Correlation between Index dimensions (Ecological, Social, Economic and Institutional) and the Sustainability index.

\begin{tabular}{|l|r|r|r|r|}
\cline { 2 - 5 } \multicolumn{1}{c|}{} & SOCindex & ECONindex & INSindex & SUSindex \\
\hline ECOLindex & -.065 & $-.211^{*}$ & -.173 & $.229^{*}$ \\
\hline SOCindex & 1 & $.353^{* *}$ & $.453^{* * *}$ & $.680^{* * *}$ \\
\hline ECONindex & & 1 & $.387^{* * *}$ & $.739^{* * *}$ \\
\hline INSindex & & & 1 & $.671^{* * *}$ \\
\hline
\end{tabular}

${ }^{*} p<0.05 ;{ }^{* *} p<0.005 ;{ }^{* * *} p<0.001$

the ECONindex and SOCindex. This represents a negative effect on sustainable development. Cluster C comprises low values for the ECONindex, but high ones for the ECOLindex and INSindex, which means that this group has positive ecological and institutional effects, but will not generate a good economic impact on the territory. Moreover, a detailed comparison between the clusters shows that cluster B evinces lower values for indices than clusters $\mathrm{A}$ and $\mathrm{C}$ : the worst effect on sustainable development is thus generated by cluster B. Cluster $\mathrm{C}$ reveals lower values than cluster A for ECONindex, INSindex and SUSindex, although values are higher for ECOLindex, which makes C more conscious of ecological impact than $\mathrm{B}$, to the detriment of the economic and institutional impacts.

\section{Correlation between sustainability and its four} dimensions

From the data provided in Table 3, we perceive the relationships between the different indices calculated, a perception confirmed by analysis of the correlations between the different indices (Table 5). Table 5 reveals

Table 6 - Sustainability index and its dimensions (Ecological, Social, Economic and Institutional) by type of natural area.

\begin{tabular}{|c|c|c|c|c|c|}
\hline & $\begin{array}{l}\text { Natural Areas of } \mathrm{Na} \text { - } \\
\text { tional Interest }(n=3)\end{array}$ & $\begin{array}{l}\text { Nature } R e- \\
\text { serves }(n=1)\end{array}$ & $\begin{array}{l}\text { Natural } \\
\text { Parks }(n=37)\end{array}$ & \begin{tabular}{|l} 
Protected Mountain Areas \\
(Natura 2000 network) $(\mathrm{n}=54)$
\end{tabular} & \multirow[t]{2}{*}{ Kruskal-Wallis } \\
\hline & \multicolumn{4}{|c|}{ Mean (SD) } & \\
\hline ECOLindex & $5.89(0.96)$ & $8.50(-)$ & $5.46(1.27)$ & $5.09(1.81)$ & $\mathrm{H}(3)=4.295, p=0.231$ \\
\hline SOCindex & $3.50(1.26)$ & $3.83(-)$ & $4.19(1.27)$ & $4.01(1.17)$ & $H(3)=0.950, p=0.810$ \\
\hline ECONindex & $1.89(2.41)$ & $1.33(-)$ & $3.34(2.65)$ & $3.65(2.43)$ & $H(3)=2.580, p=0.460$ \\
\hline INSindex & $6.62(0.99)$ & $5.91(-)$ & $6.05(1.48)$ & $6.34(1.46)$ & $H(3)=1.290, p=0.730$ \\
\hline SUSindex & 4.47 (1.39) & $4.90(-)$ & $4.74(1.05)$ & $4.78(1.01)$ & $H(3)=0.250, p=0.970$ \\
\hline
\end{tabular}

Table 7 - Sustainability index and its dimensions (Ecological, Social, Economic and Institutional) by type of organization.

\begin{tabular}{|c|c|c|c|c|c|c|c|c|}
\hline & \begin{tabular}{|l} 
Group I \\
$(n=47)$
\end{tabular} & $\begin{array}{l}\text { Group II } \\
(\mathrm{n}=11)\end{array}$ & $\begin{array}{l}\text { Group III } \\
(n=10)\end{array}$ & \begin{tabular}{|l} 
Group IV \\
$(n=12)$
\end{tabular} & \begin{tabular}{|l} 
Group V \\
$(\mathrm{n}=5)$
\end{tabular} & \begin{tabular}{|l} 
Group VI \\
$(n=10)$
\end{tabular} & \multirow[t]{2}{*}{ Kruskal-Wallis } & \multirow[t]{2}{*}{$\begin{array}{l}\text { Comparisons by } \\
\text { Mann-Whitney }\end{array}$} \\
\hline & \multicolumn{6}{|c|}{ Mean (SD) } & & \\
\hline ECOLindex & $5.56(1.53)$ & 4.79 (1.53) & $4.70(1.80)$ & 4.51 (1.31) & $6.43(1.90)$ & $5.53(1.83)$ & $H(5)=8.56$ & $I V^{*}<\mathrm{I}, \mathrm{V}$. \\
\hline SOCindex & $4.45(1.20)$ & $3.96(1.24)$ & $3.22(1.11)$ & $4.57(1.15)$ & $5.04(2.15)$ & $4.02(1.23)$ & $H(5)=12.05^{*}$ & III**<I, IV. \\
\hline \begin{tabular}{|l|} 
ECONindex \\
\end{tabular} & $3.21(1.86)$ & $1.89(1.50)$ & $2.52(1.83)$ & $7.00(1.18)$ & $5.00(1.50)$ & $2.47(1.74)$ & $\mathrm{H}(5)=28.74^{* * * *}$ & $\begin{array}{c}\mathrm{IV}^{* * * *}>\mathrm{I}, \mathrm{II}, \mathrm{III}, \mathrm{Vl} ; \\
\mathrm{V}>\mathrm{I}^{*} . \| \mathrm{II}^{* * *}, \mathrm{II}^{*}, \mathrm{~V} \mathrm{~V}^{* *}\end{array}$ \\
\hline \begin{tabular}{|l|} 
INSindex \\
\end{tabular} & $6.41(1.15)$ & $6.00(1.70)$ & $4.96(2.14)$ & $6.88(1.11)$ & $5.90(1.36)$ & $6.30(1.52)$ & $H(5)=6.92$ & III*<I, IV. \\
\hline SUSindex & $4.91(0.82)$ & $4.16(0.96)$ & $3.86(0.80)$ & $5.78(0.62)$ & $5.59(0.45)$ & $4.58(0.91)$ & $\mathrm{H}(5)=30.30^{* * * *}$ & 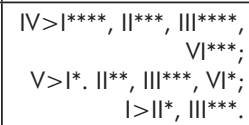 \\
\hline
\end{tabular}

$I=$ Group I, sports associations or sports clubs; $I I=$ group II, associations (non-sporting); III = group III, town councils; IV = group IV, events companies; $V=$ group $V$, others; $V I=$ group $V I$, co-organized. ${ }^{*} p<0.05$; ${ }^{*} p<0.01$; ${ }^{* *} p<0.005$; *** $p<0.001$ 
significant correlations between various dimension indices and the SUSindex: all dimensions correlate with the SUSindex. On the other hand, the ECOLindex correlates negatively with the ECONindex.

In general, the correlations observed reveal that those trail races which have a specific effect (positive or negative) on the economic dimension have the same effect on the social and institutional dimensions, although they have the opposite effect on the ecological dimension.

Relationships between sustainability and its four dimensions and type of natural protected area

In terms of the type of protected natural area in which the races were held, no significant differences were observed in the sustainability index or in the dimension indices (Table 6). Moreover, no significant differences were found in the comparisons between the density of races organized in each protected natural area and the degree of protection of the natural area.

Relationships between sustainability and its four dimensions and type of organization

Table 7 shows that significant differences were observed between the type of organization (private organizations: sports associations or clubs, non-sporting associations, events companies, other companies, coorganized; public organizations: town councils) and the sustainability index, on the one hand, and between the type of organization and the dimension indices on the other, particularly for the economic, institutional and sustainability indices. Although there is no significant association between the ECOLindex and the type of organization, events companies have significantly lower values than sports associations, clubs or other entities. Where the social dimension is concerned, the SOCindex is lower for public organizations than private ones. The effect on the economic dimension is greater in the case of events companies and other types of organizations than in the case of sports associations or clubs, non-sporting associations, town councils, and co-organized structures. The effect on the institutional dimension is lower in the case of town councils than for sports associations or clubs and events companies. Lastly, the global effect on the area's degree of sustainability is greater in the case of events companies and other types of organization than for sports associations or clubs, non-sporting associations, town councils, and co-organized structures. Moreover, the SUSindex is greater for sports associations or clubs than for non-sporting associations and town councils.

We observe, therefore, that the type of organization which managers belong to is a major factor when it comes to ascertaining which trail races make a more beneficial contribution to the sustainable development of the area: trail races organized by events companies are the most sustainable, while those organized by town councils are the least.

\section{Discussion and conclusions}

Analysis of the effects of trail races on each of the dimensions, as well as on the global level of sustainable development, has allowed us to identify those trail races that are produced using the most exemplary practices. The results of this and previous studies (Inglés 2013; Inglés et al. 2016) show that in most of the races, when there is a positive effect on one specific dimension, the same effect exists on the other dimensions, as well as on the sustainable development of the area. Nonetheless, it must be stressed that in the case of the ecological and economic dimensions, a high value in one generates a low value in the other and vice versa. Moreover, we have noted that the values of the indices for each dimension in the same race are reasonably similar to each other, which denotes a certain interdimensional balance, coinciding with previous studies (Liu 2003; Cottrell et al. 2007; Barajas et al. 2012).

Contrary to what we expected, this study has found no differences in the degree of sustainable development in terms of the kind of protected natural area in which trail races take place. Similarly, neither has a relationship been observed between the density of races and the type of protected natural area. Possible explanations might be the lack of specific regulations governing trail races in Catalonia, or else the fact that the managers of protected natural areas have not followed the recommendations of the Federación Española de Deportes de Montaña y Escalada (2011) to bring conservation measures to bear on open-air events. Other studies also show the need for specific regulation (Havlick et al. 2016), or lack of knowledge on the part of the managers of protected areas ( $\mathrm{Ng}$ et al. 2018).

Another major finding is that the effect on the degree of sustainable development of the area varies according to the kind of organization responsible for the races (Garrod \& Fyall 2000; Andersson \& Getz 2009). In this context, the most professional organizing entities tend to generate more positive effects on sustainable development, as Henderson (2011) also points out in his study. On the other hand, Henderson (2011) also contends that non-profit entities are more concerned with generating positive effects on the noneconomic dimensions than profit-making entities are, although the results obtained in the present study suggest the opposite.

Lastly, this study constitutes a measuring tool by which both trail-race managers and protected mountain area managers may calculate the degree of sustainable development that trail races generate and, on the basis of this diagnosis, counteract the negative effects and potentiate the positive ones. The study offers four indicator indices and a final sustainability index. The sustainability index represents a major advance in both research and management fields. However, this work is impaired by several limitations that must be considered when applying our results. One limitation is the fact that sustainability issues were assessed using the 
perceptions of the trail races' managers themselves; although all the information obtained through the interviews was completely objective, impact quantitative data should be considered for future studies. By using new methodological techniques, the indicators used for the measurement of the effects in the different dimensions of sustainable development could be improved: for example, real-time tests for changes in the natural conditions of the environment, surveys of the perception of social effects, or post-event economic impact assessments. Another limitation is not having considered the perceptions of other agents (such as participants or spectators) with regard to organizational issues. While we have established indices of the four dimensions of sustainability that take into account a finite number of indicators in each case, many more indicators could have an impact on the ecological, economic, social or institutional dimensions of the natural area. Further analyses are therefore needed to extend this and previous studies. Hence, these limitations highlight a compelling opportunity for future work.

In conclusion, this article provides a description of the impact generated by trail races on the sustainable development of an area as well as proposing a method by which to analyse the impact.

\section{Acknowledgments}

This study enjoyed the support of the Institut $\mathrm{Na}$ cional d'Educació Física de Catalunya (INEFC) of the Generalitat de Catalunya, and was also supported by the Grup d'Investigació Social i Educativa de Activitat Física i l'Esport (GISEAFE).

\section{References}

Agha, N. \& M. Taks 2015. A Theoretical Comparison of the Economic Impact of Large and Small Events. International Journal of Sport Finance 10(3): 199216.

Andersson, T.D. \& D. Getz 2009. Tourism as a mixed industry: Differences between private, public and notfor-profit festivals. Tourism Management 30(6): 847-856. http://doi.org/10.1016/j.tourman.2008.12.008

Barajas, Á., J. Salgado \& P. Sánchez 2012) Problemática de los estudios de impacto económico de eventos deportivos. Estudios de Economía Aplicada 30(2): 441-461. http://doi.org/https://ssrn.com/ abstract $=2233273$ [In Spanish]

Cottrell, S.P., J. J. Vaske \& P. Ritter 2007. Resident perceptions of sustainable tourism in Chongdugou, China. Society and Natural Resources 20(6): 511-525. http://doi.org/10.1080/08941920701337986

Djaballah, M., C. Hautbois \& M. Desbordes 2015. Non-mega sporting events' social impacts: a sensemaking approach of local governments' perceptions and strategies. European Sport Management Quarterly 15(1): 48-76. http://doi.org/10.1080/16184742.201 4.1000353
Dredge, D. \& M. Whitford 2010. Policy for sustainable and responsible festivals and events: institutionalisation of a new paradigm - a response. Journal of Policy Research in Tourism, Leisure and Events 2(1): 1-13. http://doi.org/10.1080/19407960903542235

Federación Española de Deportes de Montaña y Escalada 2011. Incidencia socioeconómica y ambiental de las carreras por montaña en el medio rural y natural en España. Available at: http://www.fedme.es/index. php?mmod=staticContent\&IDf=239 [In Spanish]

Garrod, B. \& A. Fyall 2000. Managing heritage tourism. Annals of Tourism Research 27(3): 682-708. http://doi. org/10.1016/S0160-7383(99)00094-8

Getz, D. \& T. Andersson 2016. Analyzing whole populations of festivals and events: an application of organizational ecology. Journal of Policy Research in Tourism, Leisure and Events 8(3): 249-273. http:/ / doi.or $\mathrm{g} / 10.1080 / 19407963.2016 .1158522$

Getz, D. \& A. McConnell 2014. Comparing Trail Runners and Mountain Bikers: Motivation, Involvement, Portfolios, and Event-Tourist Careers. Journal of Convention \& Event Tourism 15(1); 69-100. http://doi. org/10.1080/15470148.2013.834807

Getz, D. \& S.J. Page 2016. Event studies: Theory, research and policy for planned events ( $3^{\text {rd }}$ ed.). Abingdon: Routledge.

Gibson, H.J., K. Kaplanidou \& S.J. Kang 2012. Small-scale event sport tourism: A case study in sustainable tourism. Sport Management Review 15(2): 160170. http://doi.org/10.1016/j.smr.2011.08.013

Havlick, D.G., E. Billmeyer, T. Huber, B. Vogt \& K. Rodman 2016 . Informal trail creation: hiking, trail running, and mountain bicycling in shortgrass prairie. Journal of Sustainable Tourism 24(7): 1041-1058. http:/ / doi.org/10.1080/09669582.2015.1101127

Henderson, J.C. 2007. Corporate social responsibility and tourism: Hotel companies in Phuket, Thailand, after the Indian Ocean tsunami. International Journal of Hospitality Management 26(1): 228-239. http://doi. org/10.1016/j.ijhm.2006.02.001

Henderson, S. 2011. The development of competitive advantage through sustainable event management. Worldwide Hospitality and Tourism Themes 3(3): 245-257. http://doi.org/10.1108/17554211111142202

Hoffman, M.D., J.C. Ong \& G. Wang 2010. Historical analysis of participation in $161 \mathrm{~km}$ ultramarathons in North America. The International Journal of the History of Sport 27(11): 1877-1891. http://doi.org/10.1080/0 9523367.2010.494385

Inglés, E. 2013. Estratègies de gestió de la pràctica esportiva al medi natural per al desenvolupament sostenible: Un estudi de casos sobre governança i "stakeholders". Universitat de Barcelona. Available at: http://www.tdx.cat/ handle/10803/279214 [In Spanish]

Inglés, E. \& N. Puig 2015. Sports management in coastal protected areas. A case study on collaborative network governance towards sustainable development. Ocean \& Coastal Management 118: 178-188. http://doi. org/10.1016/j.ocecoaman.2015.07.018 
Inglés, E., N. Puig \& V. Labrador 2016. Sports management in protected mountain areas. Sustainable development through collaborative network governance: a case study. eco.mont-Journal on Protected Mountain Areas Research 8(2): 53-61. http://doi.org/10.1553/ eco.mont-8-2s53

International Trail Running Association 2013. Definition of trail running. Available at: http://www.itra.org/page/259/Definition_of_trail-running.html (27/04/2016)

Kerwin, S., S. Warner, M. Walker \& J. Stevens 2015. Exploring sense of community among small-scale sport event volunteers. European Sport Management Quarterly 15(1): 77-92.

Liu, Z. 2003. Sustainable Tourism Development?: A Critique. Journal of Sustainable Tourism 11(6): 459475. http://doi.org/10.1080/09669580308667216

Luque Valle, P., A. Baena-Extremera \& A. Granero-Gallegos 2011. Buenas prácticas para un desarrollo sostenible en los eventos deportivos en el medio natural. Interciencia 36(7): 531-537. [In Spanish]

Ng, S.-L., Y.-F. Leung, S.-Y. Cheung \& W. Fang 2018. Land degradation effects initiated by trail running events in an urban protected area of Hong Kong. Land Degradation \& Development 29(3): 422-432. http:/ / doi.org/10.1002/ldr.2863

Richards, G., M.P. Brito \& L. Wilks 2013. Exploring the social impacts of events. Abingdon: Routledge.

Ropits Social Running 2016. Runedia. Available at: http://www.runedia.com/ (29/04/2016)

Spangenberg, J.H. 2002a. Environmental space and the prism of sustainability: Frameworks for indicators measuring sustainable development. Ecological Indicators 2(3): 295-309. http://doi.org/10.1016/S1470160X(02)00065-1

Spangenberg, J.H. 2002b. Institutional sustainability indicators: An analysis of the institutions in Agenda 21 and a draft set of indicators for monitoring their effectivity. Sustainable Development 10(2): 103-115. http://doi.org/10.1002/sd.184

Taks, M. 2013. Social sustainability of non-mega sport events in a global world. European Journal for Sport and Society 10(2): 121-141. http://doi.org/10.1080/16 184742.2014.882370

The Outdoor Foundation 2010. A Special Report on Trail Running 2010. Available at: http://www. outdoorfoundation.org/pdf/research.trailrunning.pdf

Veltri, F.R., J.J. Miller \& A. Harris 2009. Club sport national tournament?: economic impact of a small event on a mid-size community. Recreational Sports Journal 33: 119-128. http://doi.org/10.1123/rsj.33.2.119

\section{Authors}

Joan Babí

Joan Babí is a PhD student in Sports Sciences (University of Barcelona). He holds a Master's degree in secondary education training. Main research areas: sport event management, outdoor sports. E-mail: jbabi@gencat.cat

\section{Eduard Inglés ${ }^{1}$ - corresponding author}

Eduard Inglés is a Senior Lecturer in Outdoor Sports at the National Institute of Physical Education (Barcelona) and holds a PhD in Sports Sciences (University of Barcelona). He also has a Master's degree in Citizenship and Human Rights (University of Barcelona). Main research areas: sustainable sports management, sports organizations. E-mail: eduard.ingles@ gencat.cat

\section{Susanna Soler}

Susanna Soler is a Senior Lecturer in Sport History and Theory at the National Institute of Physical Education (Barcelona) and has a $\mathrm{PhD}$ in Sports Sciences (University of Barcelona). Main research areas: ethics in sport, gender in physical education and sport. Email: ssoler@gencat.cat

${ }^{1}$ National Institute of Physical Education of Catalonia (INEFC), University of Barcelona (UB), Grup d'Investigació Social i Educativa de l'Activitat Física i l'Esport (GISEAFE), Av. Estadi, 12-22, 08038 Barcelona, Spain 